\title{
Pengaruh Pelatihan MBSR terhadap Kecemasan pada Mahasiswa Baru
}

\author{
The Effect of MBSR Training on Anxiety of College Freshman
}

\author{
Ines Rinera ${ }^{1}$, Sofia Retnowati ${ }^{2}$ \\ Fakultas Psikologi, Universitas Gadjah Mada \\ Submitted 5 Juni 2020 \\ Accepted 22 Oktober 2020 Published 28 Oktober 2020
}

\begin{abstract}
Adolescents, especially late adolescents who undergo a phase of transition to early adulthood and enter college are prone to anxiety due to changes that occur in a short amount of time. High levels of anxiety in freshman cause low academic performance and if not treated well can cause anxiety disorders. This study aimed to look at the effect of Mindfulness Based Stress Reduction training on anxiety in freshman. The participants of this study were 16 freshmen $($ male $=3$ ) at a faculty of animal science. The data collection instrument used BAI scale. This research was an experimental research using the untreated control group design. The process of analyzing data used the Mann-Whitney to test the hypothesis with the result of significance of $U=2.000, \quad p=0.001$. The results showed that MBSR training could reduce the level of anxiety of freshmen in the experimental group compared to the control group (hypothesis accepted).
\end{abstract}

Keywords: anxiety; late adolescents; freshman; MBSR; mindfulness

\begin{abstract}
Abstrak Remaja, terutama remaja akhir yang mengalami fase transisi ke dewasa awal dan masuk ke perguruan tinggi rentan mengalami kecemasan karena perubahan-perubahan yang terjadi dalam waktu yang cukup singkat. Tingkat kecemasan yang tinggi pada mahasiswa baru berpotensi menurunkan performa akademik dan jika tidak segera ditangani dapat menyebabkan masalah yang lebih serius. Penelitian ini bertujuan untuk melihat pengaruh pelatihan Mindfulness Based Stress Reduction (MBSR) terhadap kecemasan pada mahasiswa baru. Penelitian ini merupakan studi eksperimen dengan menggunakan untreated control group design. Partisipan penelitian ini berjumlah 16 orang mahasiswa baru $($ laki-laki= 3) di sebuah fakultas peternakan. Instrumen pengambilan data menggunakan skala BAI. Analisis data menggunakan uji Mann-whitney yang menunjukkan hasil signifikansi $U=2,000, p=0,001$. Hasil penelitian menunjukkan bahwa pelatihan MBSR menurunkan tingkat kecemasan mahasiswa baru (hipotesis diterima).
\end{abstract}

Kata kunci: kecemasan; mahasiswa baru; MBSR; mindfulness; remaja akhir

Korespondensi mengenai artikel ini dapat dilakukan melalui sofi53@ugm.ac.id 
Remaja akhir atau periode menjelang dewasa adalah fase kehidupan antara remaja dan dewasa dengan rentang usia 18 hingga 25 tahun (Arnett, 2000). Masa ini ditandai dengan perubahan besar, seperti kebutuhan untuk beradaptasi dengan perubahan fisik dan psikologis, pencarian identitas, pembentukan hubungan baru, dan ekspresi perasaan seksual (Santrock, 1998). Pada masa ini terjadi proses perkembangan yang berkaitan dengan perubahan akibat berubahnya pola relasi dengan orang tua dan perkembangan diri.

Selain tugas penyesuaian sosial, remaja akhir yang memasuki masa perkuliahan akan menghadapi tantangan akademis dan kognitif yang kompleks. Tantangan yang dihadapi ketika beradaptasi dengan perubahan kehidupan ini membuat mahasiswa berisiko mengalami masalah kesehatan mental seperti kecemasan yang berlebihan, depresi, dan bahkan ide bunuh diri. Dua masalah yang saat ini memengaruhi sebagian besar mahasiswa adalah tingkat kecemasan dan stres yang tinggi, terutama pada saat tahuntahun pertama dan selama periode ujian (Gallego, Aguilar-Parra, Cangas, Langer \& Mañas, 2014).

Stressor-stressor yang dialami remaja, jika tidak ditangani dengan baik akan memperburuk kecemasan kronis yang selanjutnya memengaruhi kondisi mental, kesehatan emosional, dan performa akademik, selain itu mereka menjadi rentan mengalami kecemasan yang tinggi. Kecemasan adalah masalah utama di kalangan mahasiswa di seluruh dunia. Kecemasan adalah keadaan munculnya firasat dan ketakutan terhadap sesuatu yang mungkin akan terjadi (Nevid, Rathus \& Greene, 2014). Aspek kecemasan adalah gejala-gejala kecemasan yang terdiri dari aspek fisik dan psikis. Clark dan Beck (2012) menyebutkan bahwa aspek psikis terdiri dari gejala kognitif, afektif, dan perilaku. Faktor penyebab kecemasan terdiri dari faktor internal yaitu kognitif dan biologis, serta faktor eksternal yang dipengaruhi oleh faktor di luar individu yang berpotensi memunculkan kecemasan.

Gangguan kecemasan dinilai oleh WHO sebagai penyumbang kerugian terbesar ke-9 (2,8\%) terkait masalah kesehatan non-fatal di Asia Tenggara dan penyumbang disabilitas di dunia terbesar ke-6 (3,4\%) pada tahun 2015 (World Health Organization [WHO], 2017). Berdasarkan hasil riset kesehatan dasar (Riskesdas) (Departemen Kesehatan Republik Indonesia, 2013), angka prevalensi gangguan mental emosional yang ditunjukan dengan gejala depresi dan kecemasan adalah sebesar $6 \%$ pada usia 15 tahun ke atas, atau sekitar 14 juta orang. Pendidikan di perguruan tinggi bertujuan untuk meningkatkan kemampuan intelektual dan mempersiapkan diri untuk menjadi dewasa yang produktif dan sukses, namun tingginya masalah kesehatan mental mahasiswa dapat mengganggu tercapainya tujuan tersebut.

Berdasarkan wawancara awal dengan beberapa mahasiswa baru angkatan 2018 di Universitas Gadjah Mada (Rinera, 2019), diperoleh informasi bahwa mereka umumnya mengalami kecemasan terkait pertemanan, hubungan orang tua, dan akademik. Masalah pertemanan sering terjadi pada masa remaja akhir, antara lain 
seperti remaja yang merasa kesulitan menyesuaikan diri dengan pola pertemanan di tempat baru yang memunculkan konflik, merasa sendiri, dan kesulitan mencari kelompok pertemanan yang tepat, hal ini sering mengarah pada rasa kesepian dan kecemasan. Hubungan dengan orang tua yang menjadi lebih jauh, terutama untuk para perantau dapat menjadi sumber kecemasan, mereka menjadi lebih sungkan dalam menceritakan masalah yang sedang dialami atau merasa kurang optimal merasakan dukungan karena dibatasi oleh jarak dan waktu, bahkan beberapa mengalami sakit akibat tekanan homesick. Masalah akademik yang terjadi adalah kesulitan untuk menyesuaikan diri dengan cara dan sistem belajar sehingga memunculkan pikiran untuk pindah fakultas atau jurusan dan rasa percaya diri yang rendah karena ketidakyakinan atas kemampuan diri. Selain itu, mahasiswa baru juga mengalami kekawatiran terkait penyesuaian dengan budaya baru.

Partisipan menyebutkan bahwa mereka lebih mudah tersinggung, sulit merasa santai dan merasa lelah terus menerus, serta sulit tidur. Beberapa usaha yang dilakukan oleh partisipan untuk mengatasi permasalahan adalah menceritakan kecemasan atau masalah kepada teman atau orang tua (emotionalfocused coping), problem focused coping, dipendam sendiri, atau melarikan diri (avoidance) ke kegiatan lain, hal ini berpotensi menyebabkan kecemasan yang bertambah parah, bahkan beberapa mengalami psikosomatis. Namun, afirmasi positif terhadap diri sendiri untuk menenangkan kecemasan dan mencari bantuan profesional juga dilakukan. Kecemasan yang terjadi pun dipengaruhi oleh kepribadian dan pengalaman masa lalu para remaja ini, seperti pengalaman jauh dari orang tua sebelumnya, masalah dengan orang tua, masalah pertemanan (bullying), dan lainnya.

Berdasarkan uraian di atas, perlu dilakukan intervensi untuk mengatasi kecemasan pada mahasiswa baru. Ada dua jenis intervensi untuk menurunkan kecemasan, yaitu secara medis (farmakologis) dan psikologis. Intervensi secara medis dilakukan melalui berbagai jenis obat. Intervensi secara psikologis memiliki manfaat jangka panjang karena membantu individu dalam memperoleh keterampilan yang dapat digunakan bahkan setelah perawatan berakhir.

Kini mindfulness mulai dikembangkan untuk mengatasi kecemasan. Penderita kecemasan umumnya mengaku bahwa apa yang mereka khawatirkan adalah hal yang irasional seperti yang dikemukakan oleh beberapa partisipan pada wawancara awal peneliti, namun pengakuan tidak cukup untuk mengubah perilaku menghindar atau melarikan diri saat terjadinya peningkatan stimulus (Germer, Siegel, \& Fulton, 2005). Mindfulness adalah usaha untuk menyadari kondisi saat ini dengan cara memfokuskan perhatian dan menerima tanpa menilai. Pendekatan berbasis mindfulness mencakup exposure yang merupakan penanganan paling efektif pada kecemasan (Germer et al., 2005).

Terdapat tiga komponen utama pada mindfulness, yaitu intensi, atensi, dan sikap. Ketiganya merupakan aspek yang saling terhubung dalam satu proses 
melingkar, secara bersamaan, dan saling memengaruhi. Mindfulness adalah teknik yang secara bertahap menambah atensi untuk fokus pada ketakutan seiring dengan kehadirannya, lalu mengeksplorasinya secara detail sedikit-demi sedikit melalui penerimaan. Individu mengalami perubahan secara bertahap, yaitu berubahnya perilaku menghindari ketakutan menjadi sikap toleransi terhadap ketakutan tersebut. Intervensi mindfulness memiliki aplikasi intervensi yang bervariasi, termasuk salah satunya adalah MBSR yang fokus pada sikap penerimaan. Terdapat tujuh sikap utama pada mindfulness yang menjadi dasar atas kemunculan dari sikap positif lain. Ketujuh sikap itu, antara lain tidak menghakimi/menilai, kesabaran, pemikiran pemula, kepercayaan, tidak berjuang/tidak berambisi, peneriman, melepaskan.

Program intervensi berbasis mindfulness memberikan banyak sekali manfaat, termasuk untuk mengurangi kecemasan pada remaja akhir yang memasuki usia dewasa. Melakukan intervensi dengan teknik mindfulness pada mahasiswa dapat memberikan banyak manfaat, seperti kesadaran diri, penerimaan, tanggung jawab terhadap keputusan, ketelitian pikiran, perasaan, dan tindakan, tanpa membutuhkan banyak waktu dan dengan biaya yang efisien. Halhal tersebut dapat mengarahkan pada kemampuan koping yang lebih baik dan berujung pada penurunan kecemasan.

Salah satu metode intervensi berbasis mindfulness adalah MBSR (Mindfulness Based Stress Reduction) yang diciptakan oleh Kabat-Zinn (2012). MBSR adalah metode penanganan kecemasan berbasis mindfulness yang mengembangkan sikap penerimaan dan kesadaran. Program MBSR dilaksanakan dalam format kelompok dengan seorang praktisi sebagai fasilitator. MBSR efektif untuk menangani penderita gangguan kecemasan (Kabat-Zinn, 2012; Hofmann, Sawyer, Witt, \& Oh, 2010; Vøllestad, Sivertsen \& Nielsen, 2011; Wharton, \& Kanas, 2019). Penelitian ini berusaha mengetahui efikasi MBSR terhadap mahasiswa baru sekaligus untuk menambah khasanah mengenai intervensi yang dapat mengatasi permasalahan kecemasan pada mahasiswa baru. Aspek MBSR terdiri dari mengamati, menggambarkan atau deskripsi, bertindak dengan kesadaran, dan menerima tanpa menilai. Tujuan penelitian adalah melihat pengaruh pelatihan MBSR untuk menurunkan kecemasan pada mahasiswa baru.

\section{Metode}

\section{Partisipan penelitian}

Subjek penelitian ini adalah mahasiswa baru angkatan 2019 di Fakultas Peternakan Universitas Gadjah Mada Tahun ajaran 2019/2020. Pemilihan subjek didasarkan pada kemudahan peneliti dan menggunakan metode purposive sampling. Subjek terdiri dari 16 mahasiswa Fakultas Peternakan Universitas Gadjah Mada yang bersedia terlibat dalam penelitian dengan kriteria berusia 18-20 tahun, berdomisili di Yogyakarta, tidak memiliki riwayat gangguan psikologis yang berhubungan dengan distres, belum pernah mengikuti program MBSR, bersedia terlibat dalam penelitian tanpa paksaan dan telah menandatangani lembar informed consent, 
dan memiliki tingkat kecemasan sedang sampai tinggi berdasarkan pengukuran menggunakan skala BAI.

Ke-16 mahasiswa tersebut dibagi menjadi dua kelompok, yaitu kelompok kontrol (8 orang, 7 perempuan) dan kelompok eksperimen (8 orang, 6 perempuan). Awalnya kelompok eksperimen berjumlah 9 orang, namun 1 orang tidak menghadiri 3 dari 4 pertemuan dan tidak mengikuti follow up sehingga tersisa 8 partisipan kelompok eksperimen. Partisipan mendapatkan uang tunai sejumlah Rp15.000,00/pertemuan sebagai reward yang diberikan setelah perlakuan selesai.

Penelitian ini merupakan eksperimen kuasi, yaitu untreated control group design with dependent pretest and posttest samples (Shadish, Cook \& Campbell, 2002).

\section{Perlakuan}

Intervensi pada penelitian ini menggunakan Program Mindfulness Based Stress Reduction (MBSR). Program ini menggunakan modul Mindfulness Based Stress Reduction (MBSR), ditulis oleh Munazilah (2019) yang merupakan hasil modifikasi dari Modul Program Mindfulness untuk menurunkan depresi pada orang dengan HIV/AIDS (Jauhari, 2016). Penelitian ini menggunakan lima teknik MBSR, yaitu meditasi napas, meditasi duduk, meditasi deteksi tubuh, meditasi jalan, dan meditasi makan.

Peserta ditugaskan untuk melakukan latihan mandiri di luar pertemuan untuk memperkuat dan membiasakan latihan meditasi. Instrumen yang digunakan saat latihan meditasi mandiri adalah MP3 untuk mendengarkan instruksi, buku panduan untuk membaca instruksi dan penjelasan materi, serta buku harian untuk menuliskan pengalaman diri setelah melakukan meditasi. MP3 dibuat oleh peneliti berdasarkan modul MBSR yang disusun oleh Munazilah (2019). Peneliti merekam suara melalui alat perekam, lalu menyunting hasilnya di perangkat lunak Adobe Audition untuk menghilangkan bising dan menyatukannya dengan musik meditasi instrumental. MP3 diberikan pada partisipan melalui grup whatsapp, terdapat satu MP3 untuk masingmasing teknik meditasi. MP3 berdurasi 3 menit hingga 14 menit. Buku panduan dan buku harian yang digunakan dalam penelitian ini mengikuti format yang disusun oleh Munazilah (2019).

\section{Metode analisis dan interpretasi data}

Analisis data kuantitatif untuk menguji hipotesis dilakukan dengan menggunakan Teknik Mann-Whitney Test untuk melihat perbedaan tingkat kecemasan partisipan eksperimen yang dibandingkan dengan kelompok kontrol dan Wilcoxon matchedpairs signed-ranks test untuk melihat perbedaan tingkat kecemasan partisipan eksperimen sebelum dan sesudah pemberian perlakuan, serta untuk memeriksa perbedaan tingkat kecemasan posttest dan follow up pada kelompok eksperimen.

\section{Hasil}

Hasil skor pretest menggunakan skala BAI menunjukkan bahwa seluruh partisipan berada dalam kategori tinggi, dengan kelompok eksperimen yang memiliki 
Tabel 1.

Statistik Deskriptif Skor BAI

\begin{tabular}{llccccc}
\hline \multicolumn{1}{c}{ Kelompok } & Pengukuran & N & Min & Max & Mean & $\begin{array}{c}\text { Standar } \\
\text { deviasi }\end{array}$ \\
\hline Eksperimen & Pretest & 8 & 34 & 53 & 42,3 & 5,6 \\
& Posttest & 8 & 16 & 50 & 34,6 & 10,1 \\
\multirow{2}{*}{ Kontrol } & Pretest & 8 & 32 & 41 & 34,5 & 2,9 \\
& Posttest & 8 & 31 & 41 & 35,5 & 3,4 \\
\hline
\end{tabular}

rentang 34-53 poin, sedangkan kelompok kontrol yang memiliki rentang 32-41 poin. Peneliti tetap meneruskan proses intervensi dengan partisipan karena sesuai dengan kriteria partisipan, yaitu berada dalam kategori tinggi dalam skor BAI. Selain itu berdasarkan hasil wawancara dengan partisipan kelompok eksperimen, seluruh partisipan eksperimen mengalami kekhawatiran terus-menerus karena masalah yang berbeda-beda. Hal ini menunjukkan bahwa tingkat kecemasan pada pada partisipan masih perlu diintervensi.

Berdasarkan hasil penelitian yang telah dilakukan, diperoleh data statistik deskriptif skor BAI sebagai berikut.

Berdasarkan Tabel 1 dapat dilihat bahwa kelompok eksperimen mengalami penurunan skor kecemasan dari sebelum (pretest) dan sesudah (posttest) perlakuan sebanyak 7,7 poin. Rerata pada kelompok kontrol menunjukkan kenaikan pada skor kecemasan dari sebelum (pretest) dan sesudah (posttest) sebesar 1 poin.

Setelah intervensi selesai diberikan, partisipan diminta untuk mengisi skala sebagai pengukuran posttest. Lalu, peneliti melakukan analisa skor mentah dari pretest, posttest, dan follow up. Seluruh partisipan dalam kelompok eksperimen mengalami penurunan kecemasan sehingga gain score bernilai positif.

Berdasarkan Uji Mann-Whitney, dapat disimpulkan bahwa hipotesis yang diajukan dalam penelitian ini dapat diterima. Artinya terdapat penurunan kecemasan yang terjadi pada partisipan, yaitu remaja akhir berstatus mahasiswa baru, pada kelompok eksperimen jika dibandingkan dengan kelompok kontrol $(U=2,000 ; \quad Z=-3,176 ; \quad p=0,001 ; \quad p<0,05)$. Penelitian ini menunjukkan bahwa program MBSR terbukti efektif untuk menurunkan kecemasan mahasiswa baru. Program MBSR memiliki effect size (sumbangan efek) sebesar 79\% terhadap penurunan tingkat kecemasan pada para partisipan. Berdasarkan hasil uji Wilcoxon, dapat disimpulkan bahwa terdapat perbedaan yang signifikan pada skor kecemasan partisipan kelompok eksperimen antara sebelum (pre-test) dan sesudah perlakuan (post-test) diberikan $(Z=-$ 2,524; $p=0,012 ; p<0,05)$.

Penurunan skor kecemasan yang signifikan menunjukkan bahwa Ha diterima dan Ho ditolak. Hal ini dimaknai bahwa hipotesis penelitian diterima, yaitu Program Mindfulness Based Stress Reduction (MBSR) dapat menurunkan kecemasan 
pada remaja akhir berstatus mahasiswa baru di Fakultas Peternakan UGM.

Peneliti menggunkan uji Wilcoxon signed-rank test untuk menganalisis data post-test dan follow-up. Hasil uji Wilcoxon menunjukkan bahwa skor follow-up dan post-test memiliki perbedaan yang tidak signifikan $(Z=-1,893 ; p=0,058 ; p>0,05)$.

Sesuai dengan skala yang digunakan untuk mengukur kecemasan, yaitu Beck Anxiety Inventory (BAI), maka terdapat tiga aspek, yaitu aspek kognitif, aspek afektif, dan somatis. Perubahan skor yang diperoleh yaitu skor kecemasan mengalami penurunan antara sebelum perlakuan (pretest) dan sesudah perlakuan (posttest). Selain itu, pada saat pengukuran follow up ketiga aspek kecemasan mengalami penurunan skor kembali. Ketiga aspek mengalami penurunan skor antara hasil pretest dan hasil posttest. Penurunan pada masing-masing aspek tersebut secara berturut-turut, yaitu aspek afektif turun sebanyak 17 poin, aspek kognitif sejumlah 1 poin, dan aspek somatis sebesar 43 poin. Penurunan terbesar terjadi pada aspek somatis.

\section{Diskusi}

Berdasarkan hasil penelitian, maka hipotesis yang diajukan dalam penelitian ini diterima, yaitu program Mindfulness Based Stress Reduction (MBSR) mampu menurunkan kecemasan pada remaja akhir berstatus mahasiswa baru di Fakultas Peternakan UGM. Hasil ini sesuai dengan penelitian Hofmann et al., (2010) yang membuktikan bahwa terapi berbasis mindfulness adalah intervensi yang menjanjikan untuk mengatasi masalah kecemasan dan suasana hati dalam populasi klinis. Di samping itu, hasil penelitian ini juga sesuai dengan penelitian eksperimen yang dilakukan oleh Dvořáková, et al. (2017) yang mengevaluasi efektivitas dan kelayakan pelatihan mindfulness untuk mempromosikan kesehatan dan kesejahteraan mahasiswa di tahun pertama perguruan tinggi, hasilnya menunjukkan bahwa terjadi peningkatan signifikan terkait kepuasan hidup siswa, dan penurunan yang signifikan terkait variabel depresi dan kecemasan.

Program MBSR terdiri dari empat aspek, yaitu mengamati, menggambarkan, melakukan dengan kesadaran, dan menerima tanpa menilai (Baer, Smith, \& Allen, 2004) yang telah diberikan pada seluruh partisipan melalui berbagai praktik meditasi dalam program. Praktik meditasi tersebut antara lain meditasi napas, meditasi duduk, meditasi deteksi tubuh, meditasi makan, dan meditasi jalan. Kelimanya bekerja dengan meningkatkan fokus pikiran individu sehingga gelombang otak berada pada gelombang alfa dan menyebabkan emosi individu menjadi tenang dan positif (Brown \& Ryan, 2003). Gelombang alfa di otak dapat meningkatkan kerja sistem saraf parasimpatis sehingga hormone stres seperti adrenalin dan epinefrin menurun (Munazilah, 2019).

Meditasi napas adalah menghayati setiap tarikan dan hembusan napas (KabatZinn, 2012). Meditasi napas adalah tenik meditasi yang dianggap paling efektif dan efisien bagi para partisipan. Seluruh partisipan mengakui bahwa meditasi yang paling cocok adalah meditasi napas. Berdasarkan pelaksanaan program MBSR, 
teknik yang paling dirasa cocok oleh seluruh partisipan adalah tenik meditasi napas dibandingkan dengan teknik meditasi lainnya. Hal ini sesuai dengan penelitian sebelumnya yang telah dilakukan oleh Munazilah (2019) yang menyatakan bahwa meditais napas efektif untuk menurunkan kecemasan, serta penelitian Feldman, Greeson, dan Senville (2010) yang membuktikan bahwa meditasi napas memiliki efektivitas yang paling baik dalam menurunkan frekuensi pikiran berulang dan respon negatif.

Meditasi duduk berfokus pada suara-suara, sensasi tubuh, napas, dan pikiran. Meditasi duduk biasanya dilakukan dengan cara duduk bersila atau duduk di atas kursi dengan postur tubuh tegap namun rileks dan telapak kaki yang menyentuh tanah. Inti dari meditasi duduk adalah menyadari napas (Kabat-Zinn, 2012). Pada awal latihan, partisipan merasa tenang, kadang larut dalam pikiran dan menjadi mengantuk sehingga tidak dapat mendengar instruksi. Ada pula partisipan yang merasakan leher bagian belakangnya yang menegang. Partisipan menyatakan bahwa meditasi duduk membuat diri lebih tenang serta kekhawatiran dan beban terasa berkurang. Kadang partisipan tidak mampu fokus karena punggung dan leher yang terasa tegang.

Meditasi deteksi tubuh membuat partisipan dapat merasakan sensasi tubuhnya, bahkan merasakan aliran darah yang mengalir pada tubuh. Beberapa partisipan merasakan sensasi yang tidak nyaman dan menyadari rasa sakit yang sebelumnya tidak disadari saat bermeditasi yang berangsur-angsur berkurang seiring berjalannya waktu meditasi. Ada pula yang merasa kesulitan merasakan bagian tubuh di awal meditasi dan hanya dapat fokus pada bagian tubuh yang tegang. Partisipan merasa meditasi deteksi tubuh bermanfaat karena dapat menyebabkan rasa tenang dan meningkatkan penerimaan walaupun membosankan dan lama. Seorang partisipan menyebutkan bahwa meditasi deteksi tubuh lebih cepat membuat tubuh terasa rileks dan tenang, ada pula yang menyebut bahwa lelah menjadi berkurang setelah melakukan teknik meditasi ini.

Meditasi jalan membuat partisipan dapat merasakan tiap gerakan kakinya dan lingkungan sekitarnya, seperti lantai yang dingin. Partisipan ada yang menyenangi meditasi jalan karena dapat membawa perasaan tenang sekaligus menikmati tiap gerakan yang dilakukan selama meditasi dan menjadi lebih tidak terburu-buru, namun ada pula yang merasa tidak cocok karena meditasi jalan yang prosesnya lama, tidak terbiasa dengan cara berjalan yang mindful, gagal berkonsentrasi karena hanya fokus untuk menyeimbangkan diri, dan bingung untuk memfokuskan diri.

Meditasi makan bertujuan agar individu dapat menyadari perilaku makan yang sedang dilakukan secara penuh. Partisipan mengaku lebih menikmati makanan yang sedang disantap dan merasa tidak terburu-buru. Namun juga ada yang merasa tidak terbiasa dengan cara makan yang perlahan. Partisipan merasakan produksi air liur yang bertambah dan merasakan sensasi unik tersendiri saat mengunyah makanan.

Meditasi mandiri yang dilakukan di luar sesi bertujuan supaya partisipan dapat membiasakan diri dengan praktik 
meditasi yang diajarkan dalam pertemuan dan membantu meregulasi emosi di tengah kesibukan sehingga dalam mengerjakan tugas akademik menjadi lebih baik. Jika individu berlatih meditasi secara rutin dan sistematis, maka meditasi mindfulness menguat dan memberikan manfaat (KabatZinn, 2012). Partisipan mengalami penurunan tingkat kecemasan karena latihan mandiri yang dilakukan secara rutin. Hasil analisis data follow up dan posttest menunjukkan bahwa tidak terdapat perbedaan yang signifikan pada skor kecemasan. Hal ini disebabkan karena partisipan tidak melakukan latihan meditasi secara rutin lagi sehingga berakibat pada peningkatan kecemasan.

Praktik yang dilakukan rutin dapat menyebabkan pembiasaan pada partisipan terhadap meditasi, manfaat yang dirasakan pun berbeda-beda. Partisipan yang terbiasa melakukan meditasi merasakan manfaat, seperti ketenangan, apresiasi diri, dan kontrol diri. Partisipan merasa lebih tenang sehingga lebih mampu dalam menyikapi masalah dan terarah dalam merencanakan sesuatu, lebih mampu mengontrol emosi, lebih fokus, tubuh terasa lebih ringan, lebih dapat bersyukur dan menerima diri/keadaan, dan fisik menjadi lebih rileks. Beberapa partisipan menyebutkan bahwa setelah melakukan meditasi, mereka merasa lebih rileks dan nyaman untuk tidur. Selain itu, partisipan pun merasa mengalami pengurangan perasaan negatif, lebih menghargai dan mensyukuri terhadap apapun yang terjadi di dalam diri. Kesulitan yang dialami partisipan selama meditasi adalah terkait mengembalikan fokus, sulitnya menyisihkan waktu, dan mood. Selain itu, suara-suara bising, masalah atau konflik yang sedang terjadi, dan kondisi tubuh yang lelah mampu mengganggu konsentrasi. Partisipan umumnya mengalami kesulitan terkait pengembalian fokus di awal pertemuan, namun seiring dengan pembiasaan para partisipan semakin mampu mengontrol pikiran yang berlalu-lalang.

$$
\text { Masing-masing partisipan }
$$

merasakan perubahan selama dan setelah mengikuti program pelatihan MBSR bersama maupun mandiri, yaitu ketenangan dan kontrol diri. Perubahan kondisi individu tersebut terjadi karena meningkatnya sistem saraf parasimpatis yang menyebabkan penurunan kecemasan dan stres melalui penurunan jumlah detak jantung serta frekuensi pernapasan dan tekanan darah yang lebih stabil (Wilkinson, McIntyre, Edwards, 2013). Jika hal tersebut dipertahankan dan bertahan lama, maka akan sangat baik dampaknya bagi kesehatan, baik secara fisik maupun psikis.

Fasilitator yang memberikan evaluasi dan feedback dapat membuat partisipan dapat menyadari apa yang sedang terjadi dan dialami oleh masingmasing partisipan, serta mengetahui apa yang sebaiknya dilakukan setelahnya. Fasilitator yang memberikan dukungan dan dorongan dapat membuat pastisipan bersikap terbuka sehingga mampu menyatakan pendapatnya atau menceritakan pengalamannya, merefleksikan perasaan partisipan dan melakukan parafrase dapat membuat partisipan merasa dipahami, melakukan klarifikasi agar partisipan tidak mengalami salah paham terkait informasi yang diberikan, merangkum materi di tiap 
pertemuan dan poin-poin penting di tiap materi dapat membuat partisipan kembali mengingat dan mempertahankan ingatannya terkait materi yang diberikan sehingga membantu keberlanjutan dari satu sesi ke sesi lainnya, mendengarkan aktif dan bersikap apresiatif dapat menyebabkan partisipan menunbuhkan rasa percaya dan dihargai oleh fasilitator.

Kekurangan dari penelitian ini terdiri dari ancaman validitas, yaitu ancaman validitas internal dan eksternal. Ancaman validitas internal, yaitu sejarah, seleksi, dan pengetesan (Shadish, et al., 2002). Sejarah adalah semua peristiwa yang terjadi di antara pretest dan posttest. Ancaman validitas seleksi dapat dilihat melalui skor BAI kelompok eksperimen dan kelompok kontrol yang tidak setara sehingga perbedaan antar kelompok sudah terlihat sebelum dilakukan perlakuan, selain itu, terdapat ketidaksetaraan jumlah jenis kelamin pada kedua kelompok, hal ini dapat terjadi akibat keterbatasan dalam seleksi dan penempatan partisipan. Pada ancaman validitas pengetesan, adanya pengukuran berulang sebanyak tiga kali pada partisipan menggunakan instrumen yang sama, yaitu saat pretest, posttest, dan follow up, hal ini kemunginan dapat menyebabkan efek belajar. Ancaman validitas eksternal adalah jumlah partisipan delapan orang yang menyebabkan hasil tidak cukup kuat untuk digeneralisasi pada mahasiswa baru. Pemberian perlakuan pada kelompok kontrol dalam penelitian perlu dipertimbangkan supaya tidak menyalahi aturan etik.

\section{Kesimpulan}

Program MBSR terbukti mampu menurunkan tingkat kecemasan pada partisipan. Berdasarkan kegiatan-kegiatan yang diberikan dalam program MBSR, para partisipan merasakan manfaat dalam menghadapi gejala kecemasan yang dialami selama menjalani aktivitas seharihari sebagai mahasiswa baru. Partisipan merasakan manfaat dari berbagai kegiatan yang ada dalam program MBSR, seperti pengenalan terkait stres, mindfulness, dan teknik-teknik meditasi melalui psikoedukasi dan praktik latihan. Secara keseluruhan, semua partisipan mengalami penurunan kecemasan setelah program MBSR selesai.

\section{Saran}

Peneliti menggunakan seluruh teknik meditasi, terutama meditasi napas yang memiliki manfaat yang paling efektif dibandingkan dengan teknik lainnya. Peneliti melakukan pendampingan dengan mengingatkan partisipan untuk tetap melakukan meditasi setelah program selesai. Peneliti dapat melakukan penelitian dengan partisipan yang lebih banyak sehingga dapat diuji menggunakan uji statistika parametrik guna dapat digeneralisasikan. Memberikan kelompok kontrol perlakuan walaupun setelah penelitian selesai (waiting list design). Peneliti selanjutnya dapat menggunakan uji manipulasi dengan mengukur tingkat mindfulness sebagai evaluasi sekunder untuk mengetahui perbedaan yang maksimal dalam kelompok eksperimen.

Partisipan rutin melakukan meditasi mandiri selama berjalannya program dan tetam menjalankan meditasi sesuai jadwal rencana meditasi mandiri jangka panjang 
yang telah disusun saat pertemuan akhir program. Pengetahuan yang didapatkan selama psikoedukasi dan pelatihan dapat dibagikan kepada rekan sesama mahasiwa.

Psikolog atau praktisi pelayanan kesehatan kampus dapat mempertimbangkan penggunaan MBSR untuk mengurangi kecemasan yang dialami mahasiswa baru.

\section{Daftar Pustaka}

Arnett, J. J. (2000). Emerging adulthood: A theory of development from the late teens through the twenties. American Psychologist, 55(5), 469-480. doi: https://doi.org/10.1037/0003$\underline{\text { 066X.55.5.469 }}$

Baer, R. A., Smith, G. T., \& Allen, K. B. (2004). Assessment of mindfulness by self-report: The Kentucky Inventory of Mindfulness Skills. Assessment, 11(3), 191-206. doi: https://doi.org/10.1177/1073191104268 $\underline{029}$

Brown, K. W., \& Ryan, R. M. (2003). The benefits of being present: Mindfulness and its role in psychological wellbeing. Journal of Personality and Social Psychology, 84(4), 822-848. doi: https://doi.org/10.1037/00223514.84.4.822

Clark, D.A. \& Beck, A.T. (2012). Anxiety and worry workbook: the cognitive behavioural solution. New York: The Guilford Press.

Departemen Kesehatan Republik Indonesia (2013). Riset Kesehatan Dasar. Jakarta: Badan Penelitian dan Pengembangan Kesehatan Kementrian Kesehatan RI.
Dvořáková, K., Kishida, M., Li, J., Elavsky, S., Broderick, P. C., Agrusti, M. R., \& Greenberg, M. T. (2017). Promoting healthy transition to college through mindfulness training with first-year college students: Pilot randomized controlled trial. Journal of American College Health, 65(4), 259-267. doi: https://doi.org/10.1080/07448481.2017. $\underline{1278605}$

Feldman, G., Greeson, J., \& Senville, J. (2010). Differential effects of mindful breathing, progressive muscle relaxation, and loving-kindness meditation on decentering and negative reactions to repetitive thoughts. Behaviour Research and Therapy, 48(10), 1002-1011. doi: https://doi.org/10.1016/j.brat.2010.06.0 $\underline{06}$

Gallego, J., Aguilar-Parra, J. M., Cangas, A. J., Langer, Á. I., \& Mañas, I. (2014). Effect of a mindfulness program on stress, anxiety and depression in university students. The Spanish Journal of Psychology, 17, E109. doi: http://doi.org/10.1017/sjp.2014.102

Germer, C. K., Siegel, R. D., \& Fulton, P. R. (2005). Mindfulness and psychotherapy. New York: Guilford Press.

Hofmann, S. G., Sawyer, A. T., Witt, A. A., \& Oh, D. (2010). The effect of mindfulness-based therapy on anxiety and depression: A metaanalytic review. Journal of Consulting and Clinical Psychology, 78(2), 169-183. doi: https://dx.doi.org/10.1037/a0018555

Jauhari, G. P. (2016). Program mindfulness untuk menurunkan depresi pada orang dengan HIVIAIDS (Tesis tidak 
dipublikasikan). Fakultas Psikologi, Universitas Gadjah Mada, Yogyakarta.

Kabat-Zinn, J. (2012). Mindfulness for beginners. Louisville: Sounds True.

Munazilah. (2019). Program Mindfulness Based Stress Reduction untuk menurunkan kecemasan pada individu dengan penyakit jantung koroner. (Tesis tidak dipublikasikan). Fakultas Psikologi, Universitas Gadjah Mada, Yogyakarta.

Nevid, J. S., Rathus, S.A, dan Green, B. (2014). Abnormal psychology in changing world (Edisi kesembilan). New Jersey: Pearson Education, Inc.

Rinera, I. (2019). Pengaruh Pelatihan MBSR terhadap kecemasan pada mahasiswa baru (Skripsi tidak dipublikasikan). Fakultas Psikologi, Universitas Gadjah Mada, Yogyakarta.

Santrock, J. W. (1998). Adolescence. New York: McGraw-Hill.

Shadish, W., Cook, T., \& Campbell, D. (2002). Experimental and quasi experimental designs for generalized causal inference. Boston: Houghton Mifflin Company.

Vøllestad, J., Sivertsen, B., \& Nielsen, G. H. (2011). Mindfulness-based stress reduction for patients with anxiety disorders: Evaluation in a randomized controlled trial. Behavior Research and Therapy, 49(4), 281-288.

Wharton, E. \& Kanas, N. (2019). Mindfulness-based stress reduction for the treatment of anxiety disorders. International Journal of Group Psychotherapy, 69(3), 362-372. doi: https://doi.org/10.1080/00207284.2019. $\underline{1599289}$

Wilkinson, M., McIntyre, D., \& Edwards, L. (2013). Electrocutaneous pain thresholds are higher during systole than diastole. Biological Psychology, 94(1), 71-73. doi: http://doi.org/10.1016/j.biopsycho.201 3.05 .002

World Health Organization (WHO). (2017). Depression and othe common mental disorders: Global health estimates. Geneva: World Health Organization 